\title{
The Impact of Selenium Fertilization on the Quality Characteristics of Spring Wheat Grain
}

\author{
Aleksandra Radawiec ${ }^{1, *}$, Beata Rutkowska ${ }^{1}\left(\right.$, Justina Anna Tidaback ${ }^{2}$, Dariusz Gozdowski ${ }^{3}{ }^{\circledR}$, \\ Tomasz Knapowski ${ }^{4}$ (D) and Wiesław Szulc ${ }^{1, *}$ \\ 1 Independent Department of Agricultural Chemistry, Institute of Agriculture, Warsaw University of Life \\ Sciences, Nowoursynowska 166, 02-787 Warsaw, Poland; beata_rutkowska@sggw.edu.pl \\ 2 University of Wisconsin-Madison, 975 University Ave., Madison, WI 53706, USA; tidaback@wisc.edu \\ 3 Department of Biometry, Institute of Agriculture, Warsaw University of Life Sciences, Nowoursynowska 166, \\ 02-787 Warsaw, Poland; dariusz_gozdowski@sggw.edu.pl \\ 4 Department of Biogeochemistry and Soil Science, Faculty of Agriculture and Biotechnology, Bydgoszcz \\ University of Technology, 85-225 Bydgoszcz, Poland; knap@pbs.edu.pl \\ * Correspondence: aleksandra_kowalczyk@sggw.edu.pl (A.R.); wieslaw_szulc@sggw.edu.pl (W.S.)
}

Citation: Radawiec, A.; Rutkowska, B.; Tidaback, J.A.; Gozdowski, D.; Knapowski, T.; Szulc, W. The Impact of Selenium Fertilization on the Quality Characteristics of Spring Wheat Grain. Agronomy 2021, 11, 2100. https://doi.org/10.3390/

agronomy11112100

Academic Editor: Francesco Serio

Received: 20 September 2021

Accepted: 14 October 2021

Published: 20 October 2021

Publisher's Note: MDPI stays neutral with regard to jurisdictional claims in published maps and institutional affiliations.

Copyright: (c) 2021 by the authors. Licensee MDPI, Basel, Switzerland. This article is an open access article distributed under the terms and conditions of the Creative Commons Attribution (CC BY) license (https:/ / creativecommons.org/licenses/by/ $4.0 /)$.

\begin{abstract}
Selenium is a micronutrient that is important for the proper functioning of the body. The research presented in this paper investigated the impact of various methods of selenium fertilization at various stages of plant growth on its content in grain and the quality properties of spring wheat (Triticum aestivum L.). Selenium fertilization did not affect the grain yield; however, it increased the selenium content in the grain. The research results showed that the accumulation of Se depends not only on the dose of the fertilizer but also on the stage of plant growth when the element is introduced. The most effective method of fertilization proved to be seed treatment and soil application combined with the foliar application at the tillering and stem elongation stages $(G+S+F 1-2)$, as well as at the stem elongation stage alone $(G+S+F 2)$. In terms of quality characteristics, the impact of selenium fertilization was observed only in the case of the falling number and the total protein content; all the parameters allowed for the grain to be classified as suitable for bread-making. Selenium fertilization can be considered as a safe way of increasing the Se content in spring wheat, which may contribute to an increase in the technological quality of the grain and its nutritional value.
\end{abstract}

Keywords: biofortification; selenium; wheat; grain; fertilization; quality

\section{Introduction}

For several decades, the global food economy has been facing serious problems related to an insufficient supply of micronutrients in the diets of billions of people. Common mineral and trace element deficiencies include iron, zinc, manganese, calcium, copper, iodine and selenium deficiencies. This problem is likely due to the fact that in recent years, production has been mainly focused on maximising yield [1]. Another reason is the insufficient supply of nutrients from the soil to the plants and thus to the food chain $[2,3]$. This results in food of low nutritional quality, thus leading to long-term negative health consequences [4]. Analysing the problem of mineral and trace element deficiencies, expert committees of the World Health Organization (WHO) and the Food and Agriculture Organization of the United Nations (FAO) divided the most important trace elements into three categories [5]: elements essential for humans, possibly essential for humans and potentially toxic trace elements. Selenium belongs to the first of the identified groups. Selenium is a naturally occurring element, which is essential for human and animal health in small amounts, but-when consumed in excess-may also be harmful. The recommended daily intake of Se for adults ranges from 50 to 200-400 $\mu \mathrm{g}$ [6,7]. Selenium has been found to be an essential component of over thirty mammalian enzymes [8]. In addition, it contributes to the reduction in cancer incidence [9]. It also plays an important 
role in the health of the immune system. Se deficiency affects more than one billion people around the world, also in developed countries, including European ones [10,11]. Long-term low selenium concentration in the blood results in health deterioration and, in extreme cases, even serious disease. For this reason, selenium deficiency is a serious global issue that needs to be addressed.

Increasing the content of Se in staple crops through appropriately selected agrotechnical methods may be an effective way to achieve the target supply of this element in the human diet, thus preventing its deficiency and ultimately leading to an improvement in the health condition of the population. Cereals are a basic component of human and livestock nutrition $[12,13]$. Wheat is considered to be a good source of nutrients and calories necessary for the proper functioning of the body [14]. It is one of the most widely grown and consumed crops all around the world. In addition, it can absorb greater amounts of selenium without adversely affecting plant growth, which makes it a suitable plant for selenium enrichment processes [15].

Appropriately selected agrotechnical treatments can also significantly affect grain quality [16-19]. Despite the fact that quality characteristics are mainly influenced by the cultivar [18], proper fertilization can also positively affect these parameters [20]. Ensuring appropriate grain quality is as important in cereal production as increasing yield, which requires constant research and observation. Due to the great importance of cereal grains as a strategic raw material in the food economy and their constantly growing consumption worldwide, careful selection of the cultivars is carried out in terms of the technological traits, taking into account the milling and baking value of grains. The most important quality parameters define the protein profile of the grain, such as gluten and protein content or the Zeleny sedimentation index [21]. What is equally important is the activity of the amylolytic enzymes, which defines the suitability of the grain for storage and baking, and is determined by the falling number method, as well as the bulk density of grain, determining its suitability for milling. So far, there has been no research addressing the impact of selenium fertilization in various stages of plant growth on the quality characteristics of spring wheat grain. Greater insight in this regard could provide guidelines for streamlining agrotechnical treatments, thus positively affecting the quality of the final product-grain.

The aim of this research was to evaluate the effects of different methods and timings of selenium fertilization of spring wheat on the selenium content in grain, flour and bran, as well as the quality characteristics of the grain. A hypothesis was adopted that selenium fertilization and the timing of fertilizer application affect selenium content in grain without negatively affecting grain quality parameters. The results may contribute to broadening knowledge regarding the possibilities of enriching plant products with this element without causing adverse effects.

\section{Materials and Methods}

\subsection{Study Area}

The research was conducted in 2020 at the Experimental Station of the Institute of Agriculture of the Warsaw University of Life Sciences in Skierniewice (51 $57^{\prime} 535^{\prime \prime} \mathrm{N}$, $20^{\circ} 9^{\prime} 254^{\prime \prime} \mathrm{E}$ ) in the form of a field trial. Weather conditions are presented in Figure 1. According to the Köppen-Geiger climatic classification [22], the research area is located in the climate zone of a humid continental climate with mild summers and rainfall all year round. These conditions are appropriate for the Polish Central.

The experiment was carried out on light, sandy soil, which according to the World Reference Base [23], belongs to Luvisol soil. The $\mathrm{pH}$ of the soil determined in 1-mol $\mathrm{KCl}$ by the potentiometric method on an automatic $\mathrm{pH}$ meter (Moga, Puszczykowo, Poland) was 4.97. This is a typical value for over half of the soils in Poland. The total content in soil of nitrogen by the Kjeldahl method was $0.76 \mathrm{~g} \cdot \mathrm{kg}^{-1}$; carbon content, as determined on the Vario Max analyser (Elementar, Langenselbold, Germany), was $8.40 \mathrm{~g} \cdot \mathrm{kg}^{-1}$; sulphur content was $0.33 \mathrm{~g} \cdot \mathrm{kg}-1$, as determined by the same method; phosphorus determined by the Egner-Riehm method was $45.57 \mathrm{mg} \cdot \mathrm{kg}^{-1}$; and potassium determined by the same 
method was $150 \mathrm{mg} \cdot \mathrm{kg}-1$. The total selenium content in the soil was determined by mineralization in aqua regia [24], then determined by atomic absorption spectrometry (AAS) using the Thermo Electronic SOLAAR M6 (Thermo Scientific, Wilmington, NC, USA). The selenium content in soil was $0.128 \mathrm{mg} \cdot \mathrm{kg}^{-1}$.

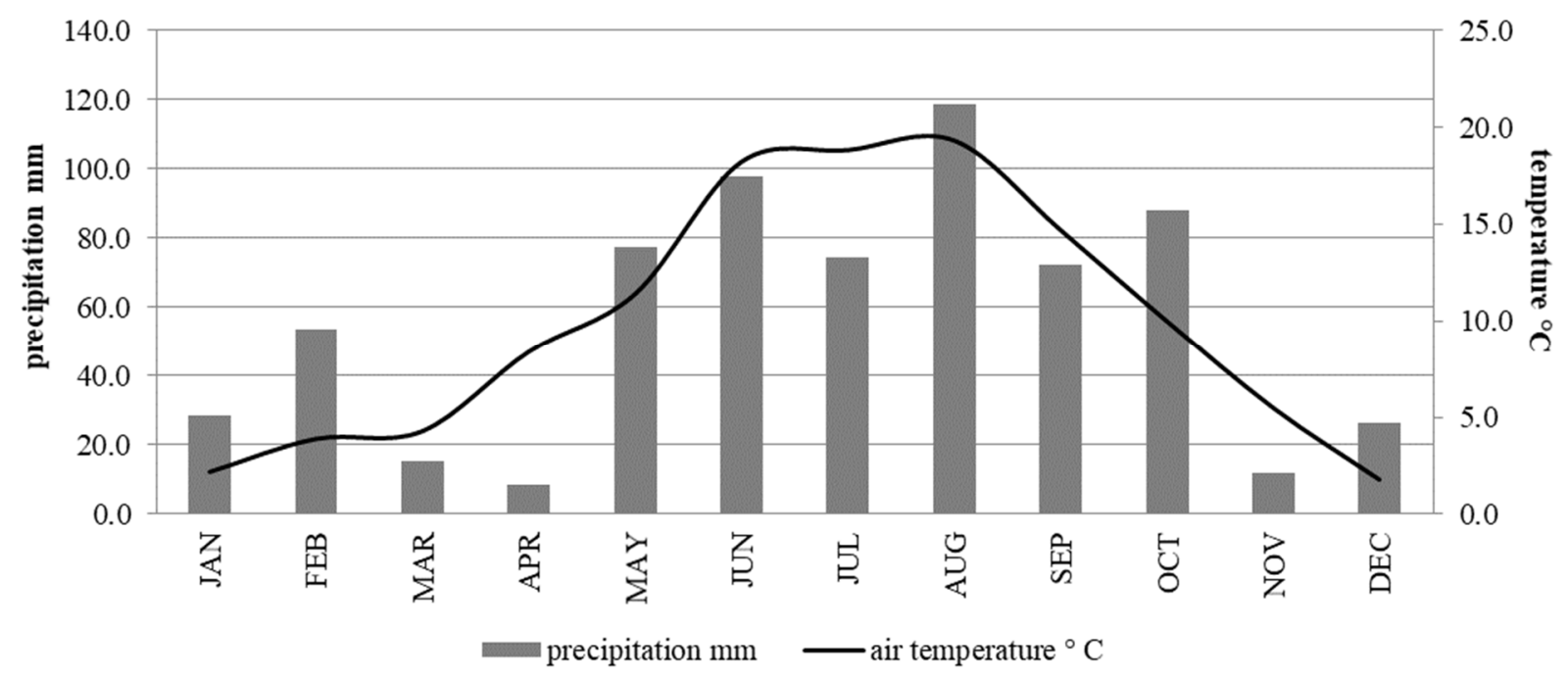

Figure 1. Monthly precipitation totals and temperature in 2020.

\subsection{Plant Growth}

The plant used for the study was spring wheat Triticum aestivum L., the cv. Mandaryna. The sowing was done with the Poznaniak seeder. The seeding density was 5 million grains per ha. Mineral fertilization was applied on all plots at the following doses: $120 \mathrm{~kg} N \cdot \mathrm{ha}^{-1}$ in the form of urea $\left(\mathrm{CO}\left(\mathrm{NH}_{2}\right)_{2}\right), 35 \mathrm{~kg} \mathrm{P} \cdot \mathrm{ha}^{-1}$ in the form of calcium dihydrogen phosphate $\left(\mathrm{Ca}\left(\mathrm{H}_{2} \mathrm{PO}_{4}\right)_{2}\right)$ and $100 \mathrm{~kg} \mathrm{~K} \cdot \mathrm{ha}^{-1}$ in the form of potassium chloride $(\mathrm{KCl})$. The research was conducted in three replications. Comprehensive chemical protection in the appropriate growth stages was used. To precisely define the stage of development, a scale was used, the abbreviation of which comes from the German Biologische Bundesanstalt, Bundessortenamt und Chemische Industrie (BBCH scale). Comprehensive chemical protection was comprised of seed dressing Oxafun T 75 DS/WS, herbicides Chwastox Trio $540 \mathrm{SL}$ and Puma Uniwersal $069 \mathrm{EW}\left(1.2 \mathrm{dm}^{3} \cdot \mathrm{ha}^{-1}-\mathrm{BBCH} 24-25\right)$, Alert $375 \mathrm{SC}$ fungicide (1.0 $\mathrm{dm}^{3} \cdot \mathrm{ha}^{-1}$ — BBCH 41-49) and insecticide Decis $2.5 \mathrm{EC}\left(250 \mathrm{~cm}^{3} \cdot \mathrm{ha}^{-1}\right.$ - BBCH 61-69).

\subsection{Selenium Fertilizers}

Selenium was introduced in the form of sodium selenate $\left(\mathrm{Na}_{2} \mathrm{SeO}_{4}\right)$. The following types of fertilization with selenium were applied: grain application $(\mathrm{G})$, soil application $(\mathrm{S})$, foliar application (F) and combined to obtain a grain and soil application $(G+S)$ (Table 1). Grain application was performed through soaking spring wheat grains in a $50.00 \mu \mathrm{mol}$ selenium solution for $24 \mathrm{~h}$ before seeding. Soil fertilization at a dose of $5.00 \mathrm{~g}$ Se $\mathrm{ha}^{-1}$ was applied before wheat seeding (spraying volume per hectare: $300 \mathrm{~L}$ ). Moreover, for each fertilization variant, foliar fertilization (F) was applied at a dose of $5.00 \mathrm{~g} \mathrm{Se} \cdot \mathrm{ha}^{-1}$ (spraying volume per hectare was $300 \mathrm{~L}$ ) at different development growth stages of the plant: F1tillering (BBCH 22), F2 - stem elongation (BBCH 32), F3-inflorescence emergence (BBCH $52)$ and F4-ripening (BBCH 85). Moreover, foliar fertilization treatments were applied at several development stages combined, where the total fertilizer dose (5.00 g Se.ha $\left.{ }^{-1}\right)$ was divided into the number of selenium applications: F1-2-tillering and stem elongation, F1-3 - tillering, stem elongation and inflorescence emergence, as well as F1-4-tillering, stem elongation, inflorescence emergence and ripening stage. 
Table 1. Research scheme.

\begin{tabular}{|c|c|c|c|}
\hline \multicolumn{2}{|l|}{ Treatment } & \multirow{2}{*}{$\begin{array}{l}\text { Dose of Se } \\
0.00 \mathrm{~g} \cdot \mathrm{ha}^{-1}\end{array}$} & \multirow{2}{*}{$\begin{array}{c}\text { Total Dose of Se } \\
0.00 \mathrm{~g} \cdot \mathrm{ha}^{-1}\end{array}$} \\
\hline Control & $\mathrm{C}$ & & \\
\hline \multirow{7}{*}{ Foliar application } & $\mathrm{F} 1$ & $5.00 \mathrm{~g} \cdot \mathrm{ha}^{-1}$ & $5.00 \mathrm{~g} \cdot \mathrm{ha}^{-1}$ \\
\hline & $\mathrm{F} 2$ & $5.00 \mathrm{~g} \cdot \mathrm{ha}^{-1}$ & $5.00 \mathrm{~g} \cdot \mathrm{ha}^{-1}$ \\
\hline & F3 & $5.00 \mathrm{~g} \cdot \mathrm{ha}^{-1}$ & $5.00 \mathrm{~g} \cdot \mathrm{ha}^{-1}$ \\
\hline & $\mathrm{F} 4$ & $5.00 \mathrm{~g} \cdot \mathrm{ha}^{-1}$ & $5.00 \mathrm{~g} \cdot \mathrm{ha}^{-1}$ \\
\hline & F1-2 & $2.50 \mathrm{~g} \cdot \mathrm{ha}^{-1}$ in each treatment & $5.00 \mathrm{~g} \cdot \mathrm{ha}^{-1}$ \\
\hline & F1-3 & $1.67 \mathrm{~g} \cdot \mathrm{ha}^{-1}$ in each treatment & $5.00 \mathrm{~g} \cdot \mathrm{ha}^{-1}$ \\
\hline & F1-4 & $1.25 \mathrm{~g} \cdot \mathrm{ha}^{-1}$ in each treatment & $5.00 \mathrm{~g} \cdot \mathrm{ha}^{-1}$ \\
\hline \multirow{8}{*}{ Grain and foliar application } & G & $50.00 \mu \mathrm{mol}$ grain & $50.00 \mu \mathrm{mol}$ \\
\hline & $\mathrm{G}+\mathrm{F} 1$ & $50.00 \mu \mathrm{mol}$ grain $+5.00 \mathrm{~g} \cdot \mathrm{ha}^{-1}$ foliar & $50.00 \mu \mathrm{mol}+5.00 \mathrm{~g} \cdot \mathrm{ha}^{-1}$ \\
\hline & $G+F 2$ & $50.00 \mu \mathrm{mol}$ grain $+5.00 \mathrm{~g} \cdot \mathrm{ha}^{-1}$ foliar & $50.00 \mu \mathrm{mol}+5.00 \mathrm{~g} \cdot \mathrm{ha}^{-1}$ \\
\hline & $G+F 3$ & $50.00 \mu \mathrm{mol}$ grain $+5.00 \mathrm{~g} \cdot \mathrm{ha}^{-1}$ foliar & $50.00 \mu \mathrm{mol}+5.00 \mathrm{~g} \cdot \mathrm{ha}^{-1}$ \\
\hline & $\mathrm{G}+\mathrm{F} 4$ & $50.00 \mu \mathrm{mol}$ grain $+5.00 \mathrm{~g} \cdot \mathrm{ha}^{-1}$ foliar & $50.00 \mu \mathrm{mol}+5.00 \mathrm{~g} \cdot \mathrm{ha}^{-1}$ \\
\hline & $\mathrm{G}+\mathrm{F} 1-2$ & $\begin{array}{c}50.00 \mu \mathrm{mol} \text { grain }+2.5 \mathrm{~g} \cdot \mathrm{ha}^{-1} \text { foliar in each } \\
\text { treatment }\end{array}$ & $50.00 \mu \mathrm{mol}+5.00 \mathrm{~g} \cdot \mathrm{ha}^{-1}$ \\
\hline & $G+F 1-3$ & $\begin{array}{c}50.00 \mu \mathrm{mol} \text { grain }+1.67 \mathrm{~g} \cdot \mathrm{ha}^{-1} \text { foliar in each } \\
\text { treatment }\end{array}$ & $50.00 \mu \mathrm{mol}+5.00 \mathrm{~g} \cdot \mathrm{ha}^{-1}$ \\
\hline & $\mathrm{G}+\mathrm{F} 1-4$ & $\begin{array}{c}50.00 \mu \mathrm{mol} \text { grain }+1.25 \mathrm{~g} \cdot \mathrm{ha}^{-1} \text { foliar in each } \\
\text { treatment }\end{array}$ & $50.00 \mu \mathrm{mol}+5.00 \mathrm{~g} \cdot \mathrm{ha}^{-1}$ \\
\hline \multirow{8}{*}{ Soil and foliar application } & $\mathrm{S}$ & $5.00 \mathrm{~g} \cdot \mathrm{ha}^{-1}$ & $5.00 \mathrm{~g} \cdot \mathrm{ha}^{-1}$ \\
\hline & $\mathrm{S}+\mathrm{F} 1$ & $5.00 \mathrm{~g} \cdot \mathrm{ha}^{-1}$ soil $+5.00 \mathrm{~g} \cdot \mathrm{ha}^{-1}$ foliar & $10.00 \mathrm{~g} \cdot \mathrm{ha}^{-1}$ \\
\hline & $\mathrm{S}+\mathrm{F} 2$ & $5.00 \mathrm{~g} \cdot \mathrm{ha}^{-1}$ soil $+5.00 \mathrm{~g} \cdot \mathrm{ha}^{-1}$ foliar & $10.00 \mathrm{~g} \cdot \mathrm{ha}^{-1}$ \\
\hline & $\mathrm{S}+\mathrm{F} 3$ & $5.00 \mathrm{~g} \cdot \mathrm{ha}^{-1}$ soil $+5.00 \mathrm{~g} \cdot \mathrm{ha}^{-1}$ foliar & $10.00 \mathrm{~g} \cdot \mathrm{ha}^{-1}$ \\
\hline & $\mathrm{S}+\mathrm{F} 4$ & $5.00 \mathrm{~g} \cdot \mathrm{ha}^{-1}$ soil $+5.00 \mathrm{~g} \cdot \mathrm{ha}^{-1}$ foliar & $10.00 \mathrm{~g} \cdot \mathrm{ha}^{-1}$ \\
\hline & $S+F 1-2$ & $\begin{array}{c}5.00 \mathrm{~g} \cdot \mathrm{ha}^{-1} \text { soil }+2.50 \mathrm{~g} \cdot \mathrm{ha}^{-1} \text { foliar in each } \\
\text { treatment }\end{array}$ & $10.00 \mathrm{~g} \cdot \mathrm{ha}^{-1}$ \\
\hline & $S+F 1-3$ & $\begin{array}{c}5.00 \mathrm{~g} \cdot \mathrm{ha}^{-1} \text { soil }+1.67 \mathrm{~g} \cdot \mathrm{ha}^{-1} \text { foliar in each } \\
\text { treatment }\end{array}$ & $10.00 \mathrm{~g} \cdot \mathrm{ha}^{-1}$ \\
\hline & $S+F 1-4$ & $\begin{array}{c}5.00 \mathrm{~g} \cdot \mathrm{ha}^{-1} \text { soil }+1.25 \mathrm{~g} \cdot \mathrm{ha}^{-1} \text { foliar in each } \\
\text { treatment }\end{array}$ & $10.00 \mathrm{~g} \cdot \mathrm{ha}^{-1}$ \\
\hline \multirow{6}{*}{$\begin{array}{l}\text { Grain, soil and foliar } \\
\text { application }\end{array}$} & $G+S$ & $5.00 \mathrm{~g} \cdot \mathrm{ha}^{-1} \mu \mathrm{mol}$ grain $+5.00 \mathrm{~g} \cdot \mathrm{ha}^{-1}$ soil & $50.00 \mu \mathrm{mol}+5.00 \mathrm{~g} \cdot \mathrm{ha}^{-1}$ \\
\hline & $\mathrm{G}+\mathrm{S}+\mathrm{F} 1$ & $\begin{array}{c}50.00 \mu \mathrm{mol} \text { grain }+5.00 \mathrm{~g} \cdot \mathrm{ha}^{-1} \text { soil }+5.00 \mathrm{~g} \cdot \mathrm{ha}^{-1} \\
\text { foliar }\end{array}$ & $50.00 \mu \mathrm{mol}+10.00 \mathrm{~g} \cdot \mathrm{ha}^{-1}$ \\
\hline & $\mathrm{G}+\mathrm{S}+\mathrm{F} 2$ & $\begin{array}{c}50.00 \mu \mathrm{mol} \text { grain }+5.00 \mathrm{~g} \cdot \mathrm{ha}^{-1} \text { soil }+5.00 \mathrm{~g} \cdot \mathrm{ha}^{-1} \\
\text { foliar }\end{array}$ & $50.00 \mu \mathrm{mol}+10.00 \mathrm{~g} \cdot \mathrm{ha}^{-1}$ \\
\hline & $\mathrm{G}+\mathrm{S}+\mathrm{F} 3$ & $\begin{array}{c}50.00 \mu \mathrm{mol} \text { grain }+5.00 \mathrm{~g} \cdot \mathrm{ha}^{-1} \text { soil }+5.00 \mathrm{~g} \cdot \mathrm{ha}^{-1} \\
\text { foliar }\end{array}$ & $50.00 \mu \mathrm{mol}+10.00 \mathrm{~g} \cdot \mathrm{ha}^{-1}$ \\
\hline & $\mathrm{G}+\mathrm{S}+\mathrm{F} 4$ & $\begin{array}{c}50.00 \mu \mathrm{mol} \text { grain }+5.00 \mathrm{~g} \cdot \mathrm{ha}^{-1} \text { soil }+5.00 \mathrm{~g} \cdot \mathrm{ha}^{-1} \\
\text { foliar }\end{array}$ & $50.00 \mu \mathrm{mol}+10.00 \mathrm{~g} \cdot \mathrm{ha}^{-1}$ \\
\hline & $\mathrm{G}+\mathrm{S}+\mathrm{F} 1-2$ & $\begin{array}{l}50.00 \mu \mathrm{mol} \text { grain }+5.00 \mathrm{~g} \cdot \mathrm{ha}^{-1} \mathrm{soil}+2.50 \mathrm{~g} \cdot \mathrm{ha}^{-1} \\
\text { foliar in each treatment }\end{array}$ & $50.00 \mu \mathrm{mol}+10.00 \mathrm{~g} \cdot \mathrm{ha}^{-1}$ \\
\hline
\end{tabular}


Table 1. Cont.

\begin{tabular}{cccc}
\hline Treatment & Dose of Se & Total Dose of Se \\
\hline & $\mathrm{G}+\mathrm{S}+\mathrm{F} 1-3$ & $\begin{array}{c}50.00 \mu \mathrm{mol} \text { grain }+5.00 \mathrm{~g} \cdot \mathrm{ha}^{-1} \text { soil }+1.67 \mathrm{~g} \cdot \mathrm{ha}^{-1} \\
\text { foliar in each treatment }\end{array}$ & $50.00 \mu \mathrm{mol}^{+10.00 \mathrm{~g} \cdot \mathrm{ha}^{-1}}$ \\
\cline { 2 - 4 } & $\mathrm{G}+\mathrm{S}+\mathrm{F} 1-4$ & $\begin{array}{c}50.00 \mu \mathrm{mol} \text { grain }+5.00 \mathrm{~g} \cdot \mathrm{ha}^{-1} \mathrm{soil}+1.25 \mathrm{~g} \cdot \mathrm{ha}^{-1} \\
\text { foliar in each treatment }\end{array}$ & $50.00 \mu \mathrm{mol}+10.00 \mathrm{~g} \cdot \mathrm{ha}^{-1}$ \\
\hline
\end{tabular}

F1 - application at the tillering stage (BBCH 22), F2 - application at the stem elongation stage (BBCH 32), F3 - application at the inflorescence emergence stage (BBCH 52), F4-application at the ripening stage (BBCH 85), F1-2-application at the stage of tillering and stem elongation, F1-3-application at the stage of tillering, stem elongation and inflorescence emergence, F1-4-application at the stage of tillering, stem elongation, inflorescence emergence and ripening.

\subsection{Sampling and Analysis}

After the harvest, the grain was weighed. The quality characteristics of grain, such as the Hagberg falling number and bulk density, were determined according to PN-EN ISO 7971-2:2019-03 [25]. The total protein content, wet gluten yield, starch content and the Zeleny sedimentation coefficient were determined in whole grain samples using an InfratecTM 1241 grain analyser (FOSS Analytical AB, Hillerød, Denmark). The material samples were dried at $50{ }^{\circ} \mathrm{C}$ with forced air circulation, then at $105^{\circ} \mathrm{C}$ to reach a constant weight [26]. Part of the grain was milled with a Retsh mill at $5000 \mathrm{rpm}$. In order to obtain flour with bran, grain milling was performed in a laboratory grain mill, type WZ-1. The flour was additionally sieved $(230 \mu \mathrm{m})$ using a laboratory sieve shaker (type SZ-1). The selenium content in grain, flour and bran was determined after mineralisation in a mixture of $\mathrm{HNO}_{3}$ and $\mathrm{HClO}_{4}$ by atomic absorption spectrometry (AAS) using the Thermo Elemental SOLAAR M6 apparatus (Thermo Scientific, Wilmington, DE, USA).

\subsection{Statistical Analyses}

The statistical analyses were performed by means of the Statgraphics 5.1. software (The Plains, VA, USA). The results were subject to single factor and multivariate analysis of variance ANOVA and t-test at a significance level of $p=0.05$, and Pearson linear correlation analysis.

\section{Results}

\subsection{Grain Yield}

In the research, the grain yield of spring wheat was determined (Figure 2). The annual precipitation in 2020 was higher compared to the average annual precipitation in 1991-2020. In turn, the mean annual temperature was, on average, higher by $1^{\circ} \mathrm{C}$. Weather conditions were unfavourable in the initial period of plant vegetation, mainly due to sowing seeds into dry soil and uneven emergence, which resulted in a lower yield.

Grain yield in the control sample (C) was $2.34 \mathrm{t} \cdot \mathrm{ha}^{-1}$, while in the selenium-fertilized samples, it ranged from 2.05 to $2.79 \mathrm{t} \cdot \mathrm{ha}^{-1}$. Despite different doses of selenium being applied to the plants, no significant impact of fertilization on grain yield was found (Table 2). In terms of the different methods of fertilization, soil application combined with the foliar application $(\mathrm{S}+\mathrm{F})$ proved to be the most effective one. The lowest yield was observed when soil fertilization was combined with the foliar application at the stage of tillering, stem elongation and inflorescence emergence $(\mathrm{S}+\mathrm{F} 1-3)$, while the highest was in the case of soil fertilization combined with the foliar application at the tillering stage $(S+F 1)$. 


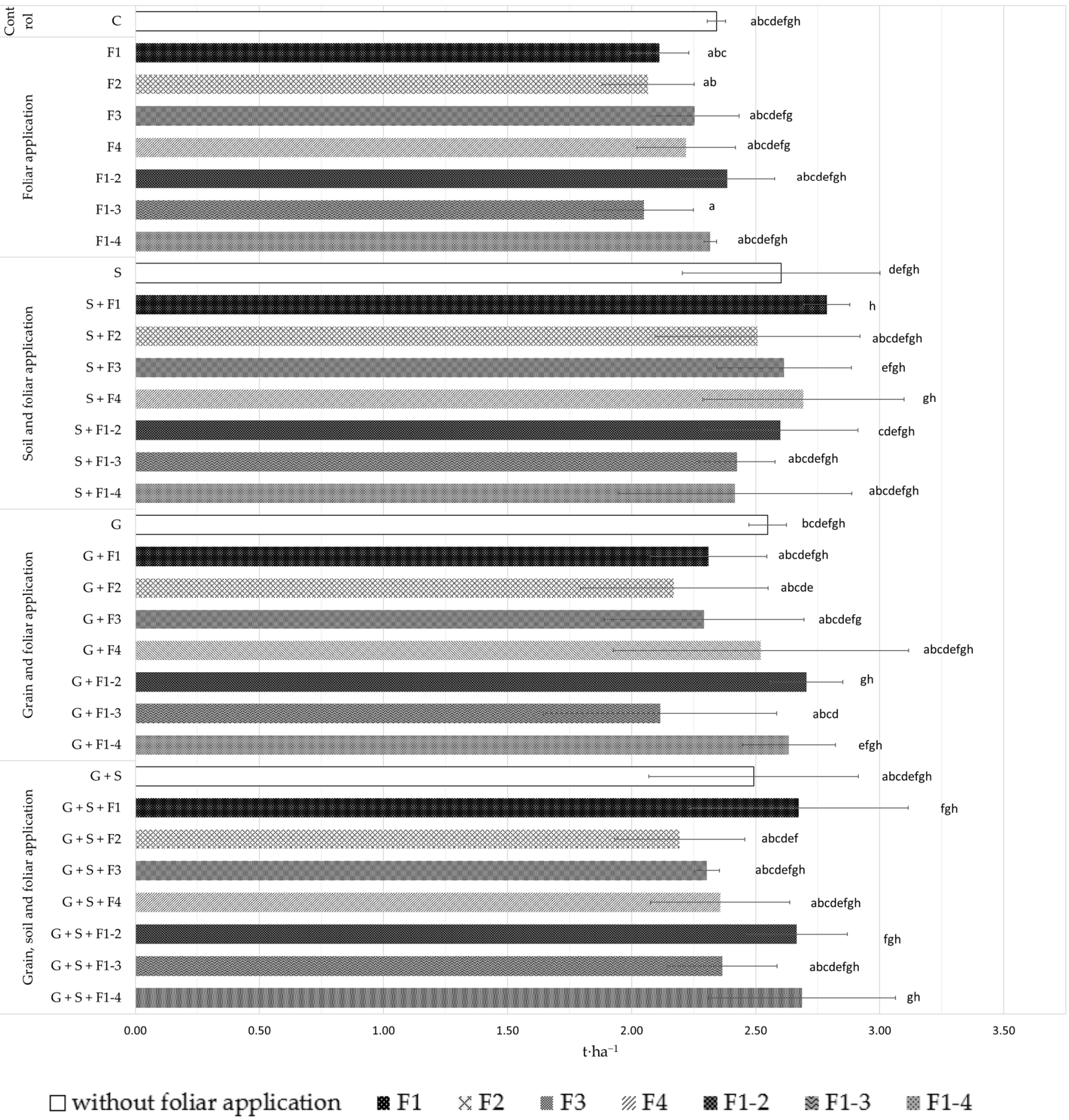

Figure 2. Average yield depending on fertilization. Results show means and standard errors $(n=3)$. a, b, c-means followed by the same letter are not significantly different from one another based on Tukey's test at $p \leq 0.05$. 
Table 2. Influence of the experimental factor on the analysed values.

\begin{tabular}{cc}
\hline Experience Factor & Fertilization and Application Time \\
\hline yield & 0.927 \\
\hline Se content in grain & 0.000 \\
\hline Se content in flour & 0.000 \\
\hline Se content in bran & 0.000 \\
\hline falling number & 0.000 \\
\hline bulk density & 0.225 \\
\hline total protein content & 0.012 \\
\hline wet gluten yield & 0.838 \\
\hline starch content & 0.977 \\
\hline Zeleny sedimentation index & 0.169
\end{tabular}

\subsection{Selenium Content in Grain}

The selenium content in the grain in the control sample (C) was $0.171 \mathrm{mg} \cdot \mathrm{kg}^{-1}$ and was lower compared to the samples treated with fertilization (Figure 3). Both the method of fertilization and the developmental stage when the foliar application was used affected the content of this element in spring wheat grain (Table 2). In all cases, treatment with selenium fertilization resulted in a higher Se content in the grain, ranging from 0.185 to $0.824 \mathrm{mg} \cdot \mathrm{kg}^{-1}$, which means that the content of this element was between 1.08 to almost 5 times higher than in the control group. The highest content of selenium in the grain was obtained for seed treatment and soil application combined with an additional foliar application at the stage of tillering and stem elongation ( $G+S+F 1-2)$. High Se content was also obtained in the case of seed treatment and soil application combined with the foliar application at the stage of stem elongation $(G$ $+\mathrm{S}+\mathrm{F} 2)$ and at the stage of tillering, stem elongation and inflorescence emergence ( $\mathrm{G}+\mathrm{S}+$ F1-3). Se content above $0.600 \mathrm{mg} \cdot \mathrm{kg}^{-1}$ was also observed in the case of soil application alone, combined with the foliar application at the stage of tillering and stem elongation (S + F1-2) and at the stage of stem elongation alone (S + F2). The least effective method was seed treatment (G). No correlation was found between selenium content in the grain and the yield (Table 3).

Table 3. Pearson linear correlation analysis.

\begin{tabular}{|c|c|c|c|c|c|c|c|c|c|c|}
\hline & Yield & $\begin{array}{c}\text { Se } \\
\text { Content } \\
\text { in Grain }\end{array}$ & $\begin{array}{c}\text { Se } \\
\text { Content } \\
\text { in Flour }\end{array}$ & $\begin{array}{l}\text { Se } \\
\text { Content } \\
\text { in Bran }\end{array}$ & $\begin{array}{l}\text { Falling } \\
\text { Num- } \\
\text { ber }\end{array}$ & $\begin{array}{l}\text { Bulk } \\
\text { Den- } \\
\text { sity }\end{array}$ & $\begin{array}{l}\text { Total } \\
\text { Protein } \\
\text { Content }\end{array}$ & $\begin{array}{l}\text { Wet } \\
\text { Gluten } \\
\text { Yield }\end{array}$ & $\begin{array}{l}\text { Starch } \\
\text { Con- } \\
\text { tent }\end{array}$ & $\begin{array}{c}\text { Zeleny Sed- } \\
\text { imentation } \\
\text { Index }\end{array}$ \\
\hline Yield & & n.d. & n.d. & n.d. & 0.429 & n.d. & n.d. & n.d. & n.d. & n.d. \\
\hline Se content in grain & & & 0.917 & 0.309 & n.d. & n.d. & 0.242 & 0.238 & -0.222 & 0.240 \\
\hline Se content in flour & & & & n.d. & n.d. & n.d. & n.d. & n.d. & n.d. & n.d. \\
\hline Se content in bran & & & & & n.d. & n.d. & n.d. & n.d. & n.d. & n.d. \\
\hline Falling number & & & & & & n.d. & n.d. & n.d. & n.d. & n.d. \\
\hline Bulk density & & & & & & & n.d. & n.d. & n.d. & n.d. \\
\hline Total protein content & & & & & & & & 0.891 & -0.798 & 0.905 \\
\hline Wet gluten yield & & & & & & & & & -0.895 & 0.918 \\
\hline Starch content & & & & & & & & & & -0.827 \\
\hline Zeleny sedimentation index & & & & & & & & & & \\
\hline
\end{tabular}

n.d.- not detected.

According to the results of the research, seed treatment and soil application with the foliar application at specific stages $(\mathrm{G}+\mathrm{S}+\mathrm{F})$ proved to be the most effective method of fertilization. None of the methods of selenium fertilization applied independently contributed 
to a significant increase in its content in the grain, as compared to the aforementioned combined methods of fertilization. This is partly due to the highest dose of selenium being supplied directly and indirectly to the plant. Significant differences can also be seen in terms of the stage in which the element was introduced (Figure 2). Despite the fact that the same doses of selenium were applied as part of a single method of fertilization, the highest selenium content in grain was usually found in the case of an additional foliar application at the tillering and stem elongation stages (F1-2) and the stem elongation stage (F2).

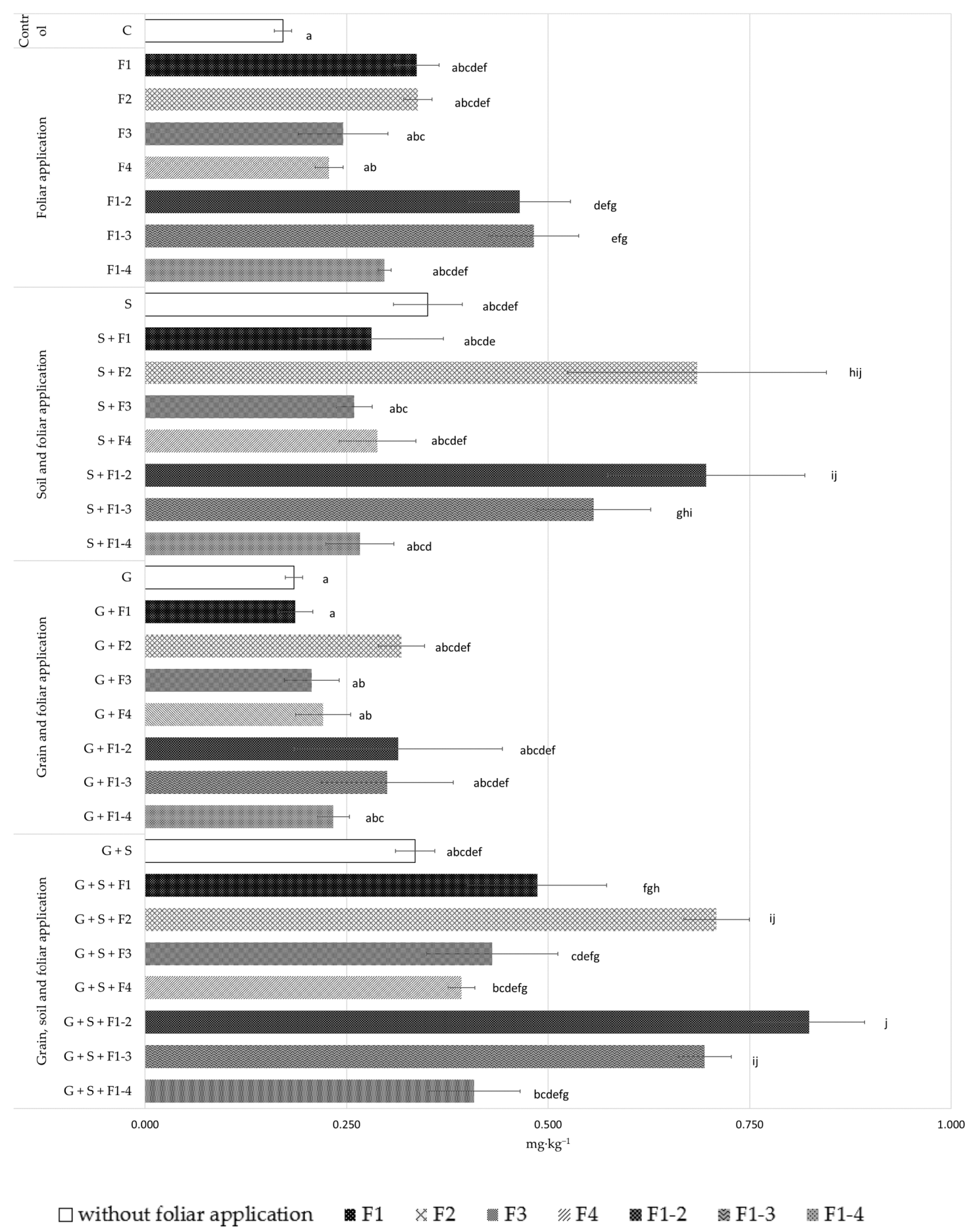

Figure 3. Grain Se depending on fertilization. Results show means and standard errors $(n=3)$. $\mathrm{a}, \mathrm{b}$, $\mathrm{c}-$ means followed by the same letter are not significantly different from one another based on Tukey's test at $p \leq 0.05$. 


\subsection{Selenium Concentration in Flour and Bran}

In order to verify in which part of the grain a greater amount of selenium is stored, the concentration of the element in question in bran (outer part of the grain) and in flour (inner part of the grain) was examined. For the control sample (C), these values were similar. However, for the grain subjected to fertilization, it was found that a higher content was located in its inner part (Figure 4). A statistically significant positive correlation was found between selenium content in grain and its content in flour. Only in the case of seed treatment $(\mathrm{G})$, the content of the analysed element was slightly higher in bran than in flour. The greatest difference between selenium content in grain and in bran (96.58\%) was found for the foliar application at the stage of ripening (F4). Considerable differences (approx. 94.55\%) were also observed in the case of foliar application at the tillering, stem elongation and inflorescence emergence stage (F1-3), as well as in the case of seed treatment and soil application (G + S). High differentiation was also observed in seed treatment and soil application combined with a foliar application at the tillering $(G+S+F 1)$. There were also significant differences in the tillering and stem elongation stages $(\mathrm{G}+\mathrm{S}+\mathrm{F} 1-2)$ and in the case of soil application combined with the foliar application at the stem elongation stage $(\mathrm{S}+\mathrm{F} 2)$.

\subsection{Subsection}

Due to the constantly growing demand for food, it is indispensable to ensure the production of high-quality grain. Quality characteristics depend on the grain cultivar and also on habitat conditions and agrotechnical factors, including selenium fertilization. In this research, the following characteristics of spring wheat grain were examined: falling number, bulk density, protein content, starch content, gluten yield and the value of the Zeleny sedimentation index (Table 4).

The fertilization method and the stage at which the selenium was applied were found to have an impact only on protein content and wet gluten yield. No impact was found for the other characteristics.

The experiment involved the determination of the falling number of the grain, which is a basic quality parameter informing about the level of activity of amylolytic enzymes in cereal grains. It is an important technological parameter of wheat grain and the flour obtained from it, affecting its baking value. Significant differences were found among various methods of fertilization and the stage of foliar application of the selenium. In the control sample (C), the falling number was $255.3 \mathrm{~s}$, while for grain treated with selenium fertilization, it ranged from $247.0 \mathrm{~s}$ for seed treatment combined with the foliar application at the stage of stem elongation $(\mathrm{G}+\mathrm{F} 2)$ to $294.7 \mathrm{~s}$ for seed treatment and soil application combined with the foliar application at the stage of tillering, stem elongation, inflorescence emergence and ripening $(\mathrm{G}+\mathrm{S}+\mathrm{F} 1-4)$. Comparing different methods of fertilization, the lowest values of this parameter were observed for the foliar application $(\mathrm{F})$ and seed treatment combined with the foliar application $(G+F)$. No correlation was found between selenium content in grain (and the remaining quality characteristics) and grain falling number.

The bulk density (the ratio of grain weight to the volume of the layer occupied by it) of spring wheat grain was determined. It is assumed that the higher the bulk density of the grain, the higher its quality. The research showed no significant differences in grain density for the different methods of selenium fertilization. In the control sample (C), it was $77.33 \mathrm{~kg} \cdot \mathrm{hl}^{-1}$ on average, while for selenium fertilization treatment using different methods, these values ranged from 76.50 to $79.14 \mathrm{~kg} \cdot \mathrm{hl}^{-1}$ for soil application combined with the foliar application at the stage of tillering, stem elongation, inflorescence emergence and ripening (S + F1-4), and seed treatment and soil application combined with the foliar application at the ripening stage $(\mathrm{G}+\mathrm{S}+\mathrm{F} 4)$, respectively. No correlation was found between the remaining grain quality characteristics.

The experiment determined the protein content in spring wheat grain, which is an extremely important quality characteristic of grain in terms of its baking value. In the control sample (C), it was $12.37 \%$. Significant differences in terms of total protein content 
were found depending on the method of fertilization and the stage at when the selenium was applied. Comparing different methods of fertilization, low total protein content in spring wheat grain was obtained in the case of seed treatment with foliar application (G + F) and the foliar application alone (F). However, the lowest content was recorded for seed treatment combined with the foliar application at the inflorescence emergence stage ( $G+$ F3), in which case the value was only $10.60 \%$. In turn, the highest content of protein was found for soil application combined with the foliar application $(\mathrm{S}+\mathrm{F})$ at the tillering and stem elongation stage ( $\mathrm{S}+\mathrm{F} 1-2)$, in which case the value was $13.73 \%$.

An equally important quality characteristic is wet gluten yield, which, similarly to total protein content, provides information regarding the baking value of the grain. The research showed that neither the method of fertilization nor the stage at which the selenium was applied influenced the value of wet gluten yield. The average value for the control sample (C) was $27.74 \%$, while in the case of fertilization treatment, the values ranged from $22.57 \%$ to $30.62 \%$ for seed treatment combined with the foliar application at the inflorescence emergence stage ( $G+F 3)$ and for soil application combined with the foliar application at the tillering and stem elongation stage (S + F1-2), respectively. The most effective method of fertilization turned out to be soil application (S) and soil application combined with the foliar application $(\mathrm{S}+\mathrm{F})$, which gave similar values. In addition, a strong positive correlation was found between wet gluten yield and total protein content.

The content of starch, the main carbohydrate present in grain endosperm, was also determined. It constitutes a source of energy and binds water, which is a desirable characteristic for baking processes. The starch content ranged from $68.73 \%$ to $70.77 \%$. For the control sample (C), it was $69.43 \%$. Thus, no impact of selenium fertilization on starch content was found. In terms of the characteristic in question, the least effective method was soil application combined with the foliar application at the ripening stage $(S+F 4)$. In turn, the highest starch content was recorded for seed treatment combined with the foliar application at the inflorescence emergence stage $(G+F 3)$. On the basis of statistical analyses, a statistically significant negative correlation was found between starch content in spring wheat grain, wet gluten yield and total protein content.

Another important indicator of grain quality is the Zeleny sedimentation index. The higher its value, the higher the content of gluten proteins, especially high-molecular-weight glutenin, which increases the baking value of flour. No impact of fertilization and foliar application was found on the value of this index. The value for the control sample (C) was $38.33 \mathrm{~cm}^{3}$, while in the case of fertilization treatment, the values ranged from 28.83 to 44.07 $\mathrm{cm}^{3}$ for seed treatment combined with the foliar application at the inflorescence emergence stage ( $G+F 3)$ and for soil application combined with the foliar application at the tillering and stem elongation stage ( $\mathrm{S}+\mathrm{F} 1-2)$, respectively. In addition, a strong positive correlation was found between the sedimentation index, total protein content and wet gluten yield. In turn, the correlation of starch content with these parameters was negative. 


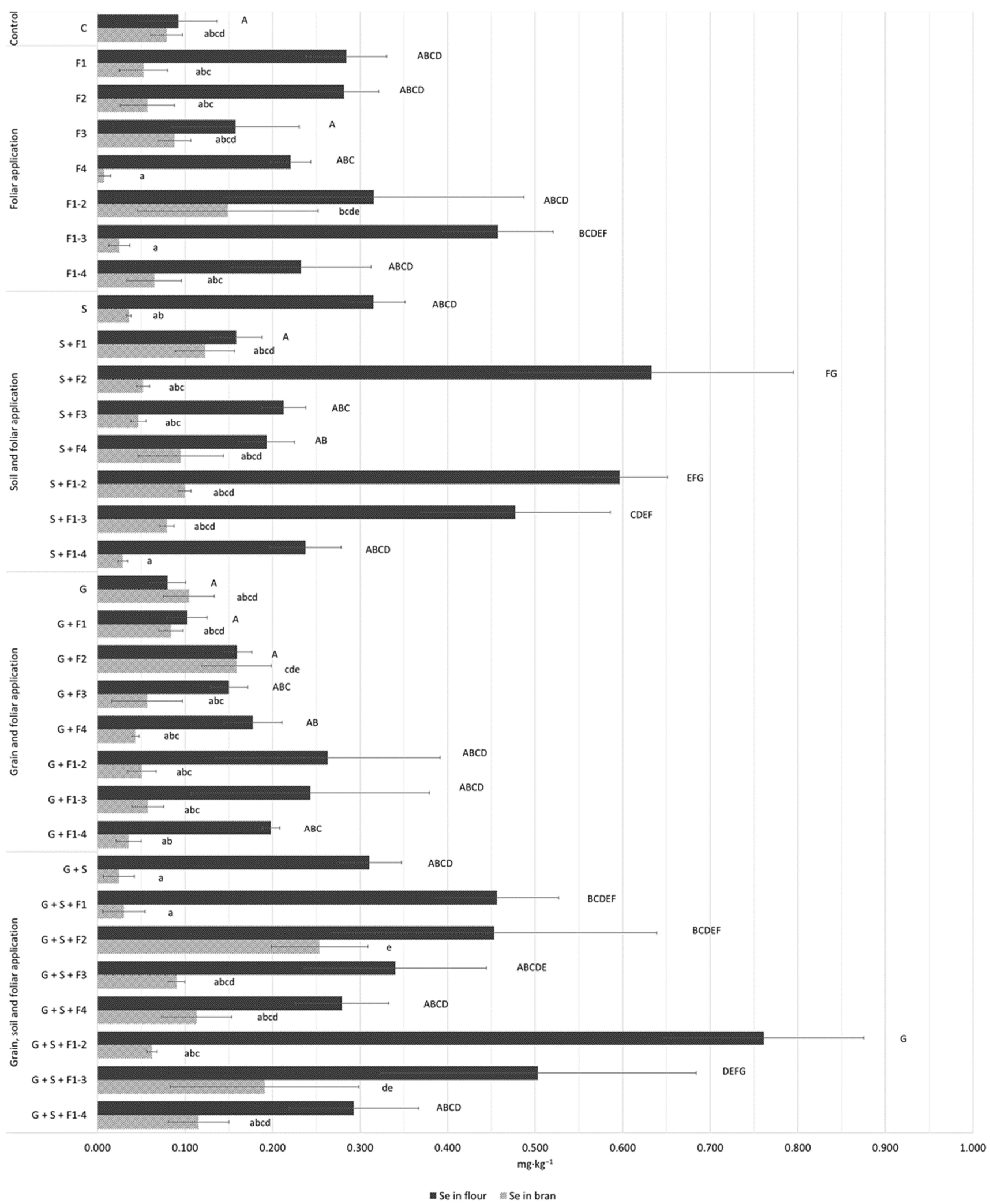

Figure 4. Se concentration in flour and bran across different Se fertilization treatments. Results show means and standard errors $(n=3)$. A, B, C-means for flour. a, b, c-means for bran. If meansare followed by the same letter, they are not significantly different from one another based on Tukey's test at $p \leq 0.05$. 
Table 4. Quality features of grain.

\begin{tabular}{|c|c|c|c|c|c|c|c|}
\hline \multicolumn{2}{|c|}{ Treatment } & \multirow{2}{*}{$\begin{array}{c}\begin{array}{c}\text { Falling Number } \\
\text { (s) }\end{array} \\
255.3 \pm 10.69^{\mathrm{abc}}\end{array}$} & \multirow{2}{*}{$\begin{array}{c}\begin{array}{c}\text { Bulk Density } \\
\left(\mathbf{k g} \cdot \mathbf{h} \mathbf{l}^{-\mathbf{1}} \mathbf{)}\right.\end{array} \\
77.33 \pm 0.69^{\mathrm{a}}\end{array}$} & \multirow{2}{*}{$\begin{array}{c}\begin{array}{c}\text { Total Protein } \\
\text { Content (\%) }\end{array} \\
12.36 \pm 0.02^{\text {bcdefgh }}\end{array}$} & \multirow{2}{*}{$\begin{array}{c}\begin{array}{c}\text { Wet Gluten Content } \\
\text { (\%) }\end{array} \\
27.74 \pm 0.94^{\mathrm{abc}}\end{array}$} & \multirow{2}{*}{$\begin{array}{c}\begin{array}{c}\text { Starch Content } \\
(\%)\end{array} \\
69.43 \pm 0.47^{\mathrm{a}}\end{array}$} & \multirow{2}{*}{$\begin{array}{c}\begin{array}{c}\text { Wskaźnik Sed. } \\
\text { Zeleny'ego }\end{array} \\
38.33 \pm 2.17^{\text {efghij }}\end{array}$} \\
\hline Control & $\mathrm{C}$ & & & & & & \\
\hline \multirow{7}{*}{ Foliar application } & F1 & $257.3 \pm 10.12^{a b c}$ & $77.17 \pm 0.57^{a}$ & $12.00 \pm 0.08^{\text {abcdefg }}$ & $26.56 \pm 2.23^{a b c}$ & $69.57 \pm 0.70^{a}$ & $34.37 \pm 2.22$ bcde \\
\hline & F2 & $249.0 \pm 12.17^{\mathrm{ab}}$ & $77.13 \pm 0.61^{\mathrm{a}}$ & $11.43 \pm 0.03^{\text {abcde }}$ & $24.77 \pm 0.75^{\mathrm{abc}}$ & $70.20 \pm 0.80^{a}$ & $32.97 \pm 1.50 \mathrm{abcd}$ \\
\hline & F3 & $274.3 \pm 11.5^{\mathrm{abcd}}$ & $77.72 \pm 0.91^{\mathrm{a}}$ & $11.27 \pm 0.01 \mathrm{abcd}$ & $24.82 \pm 0.36^{\mathrm{abc}}$ & $70.30 \pm 0.10^{a}$ & $33.93 \pm 1.50$ bcde \\
\hline & $\mathrm{F} 4$ & $252.7 \pm 9.02^{a b c}$ & $76.81 \pm 0.68^{a}$ & $11.53 \pm 0.07^{\text {abcdef }}$ & $25.61 \pm 2.31^{\mathrm{abc}}$ & $70.50 \pm 0.61^{a}$ & $33.33 \pm 0.67 \mathrm{abcd}$ \\
\hline & F1-2 & $260.3 \pm 11.24^{\mathrm{abcd}}$ & $77.57 \pm 1.14^{\mathrm{a}}$ & $11.43 \pm 0.02$ abcde & $25.4 \pm 0.57^{a b c}$ & $69.97 \pm 0.67^{a}$ & $41.10 \pm 3.22^{\text {hijk }}$ \\
\hline & F1-3 & $251.0 \pm 8.89 \mathrm{abc}$ & $77.00 \pm 0.68^{a}$ & $11.67 \pm 0.07^{\text {abcdef }}$ & $25.92 \pm 0.80^{\mathrm{abc}}$ & $69.47 \pm 0.81^{a}$ & $41.63 \pm 2.47^{\mathrm{ijk}}$ \\
\hline & F1-4 & $249.0 \pm 15.1^{\mathrm{ab}}$ & $77.52 \pm 1.08^{a}$ & $11.57 \pm 0.02$ abcdef & $25.21 \pm 0.38^{a b c}$ & $69.90 \pm 0.46^{\mathrm{a}}$ & $42.83 \pm 2.04^{\mathrm{jk}}$ \\
\hline \multirow{8}{*}{$\begin{array}{l}\text { Grain and foliar } \\
\text { application }\end{array}$} & G & $262.0 \pm 6.08^{a b c d}$ & $78.19 \pm 0.96^{a}$ & $12.23 \pm 0.03$ bcdefgh & $27.80 \pm 1.10^{a b c}$ & $69.67 \pm 0.25^{a}$ & $36.20 \pm 2.55^{\text {cdefg }}$ \\
\hline & $G+F 1$ & $272.0 \pm 11.53$ abcd & $77.63 \pm 1.82^{a}$ & $11.90 \pm 0.04$ abcdefg & $27.12 \pm 1.50^{a b c}$ & $69.77 \pm 0.31^{a}$ & $39.77 \pm 3.01^{\text {fghijk }}$ \\
\hline & $G+F 2$ & $247.0 \pm 14.8^{\mathrm{a}}$ & $78.37 \pm 0.22^{a}$ & $11.93 \pm 0.07^{\text {abcdefg }}$ & $26.47 \pm 2.40^{a b c}$ & $69.47 \pm 0.67^{\mathrm{a}}$ & $40.37 \pm 3.30^{\text {fghijk }}$ \\
\hline & $\mathrm{G}+\mathrm{F} 3$ & $284.7 \pm 10.97^{\mathrm{bcd}}$ & $78.19 \pm 0.61^{a}$ & $10.60 \pm 0.05^{\mathrm{a}}$ & $22.57 \pm 2.68^{a}$ & $70.77 \pm 0.86^{\mathrm{a}}$ & $44.07 \pm 1.56^{\mathrm{k}}$ \\
\hline & $\mathrm{G}+\mathrm{F} 4$ & $256.0 \pm 11.53^{a b c}$ & $76.81 \pm 0.45^{a}$ & $10.90 \pm 0.05^{\mathrm{ab}}$ & $23.56 \pm 1.62^{a b}$ & $70.60 \pm 0.53^{a}$ & $42.50 \pm 1.30^{\mathrm{ijk}}$ \\
\hline & $G+F 1-2$ & $271.7 \pm 12.5^{\mathrm{abcd}}$ & $77.47 \pm 1.01^{a}$ & $11.50 \pm 0.08^{\text {abcdef }}$ & $25.69 \pm 2.28^{a b c}$ & $70.10 \pm 0.79^{a}$ & $42.70 \pm 3.28^{j k}$ \\
\hline & $G+F 1-3$ & $250.0 \pm 7.55^{a b c}$ & $77.30 \pm 0.52^{a}$ & $11.57 \pm 0.13^{\text {abcdef }}$ & $25.51 \pm 3.97^{a b c}$ & $69.80 \pm 10^{a}$ & $38.30 \pm 1.82$ efghij \\
\hline & $\mathrm{G}+\mathrm{F} 1-4$ & $270.7 \pm 9.07^{\mathrm{abcd}}$ & $77.08 \pm 0.94^{\mathrm{a}}$ & $12.03 \pm 0.04^{\text {abcdefg }}$ & $26.97 \pm 1.37 \mathrm{abc}$ & $69.53 \pm 0.45^{\mathrm{a}}$ & $35.77 \pm 2.27$ cdef \\
\hline \multirow{5}{*}{$\begin{array}{l}\text { Soil and foliar } \\
\text { application }\end{array}$} & S & $259.7 \pm 8.33^{a b c d}$ & $78.21 \pm 1.29^{a}$ & $12.37 \pm 0.02^{\text {bcdefgh }}$ & $29.66 \pm 2.07^{b c}$ & $68.77 \pm 0.67^{a}$ & $33.00 \pm 2.19$ abcd \\
\hline & $\mathrm{S}+\mathrm{F} 1$ & $281.3 \pm 2.52 \mathrm{abcd}$ & $77.42 \pm 1.09^{a}$ & $12.67 \pm 0.04$ cdefgh & $29.32 \pm 2.46^{b c}$ & $69.03 \pm 0.91^{a}$ & $35.9 \pm 2.40^{\text {cdef }}$ \\
\hline & $\mathrm{S}+\mathrm{F} 2$ & $286.7 \pm 8.33^{c d}$ & $78.19 \pm 0.52^{a}$ & $12.97 \pm 0.06^{\text {efgh }}$ & $29.99 \pm 2.08^{b c}$ & $68.93 \pm 1.01^{a}$ & $28.83 \pm 1.62^{a}$ \\
\hline & $\mathrm{S}+\mathrm{F} 3$ & $263.0 \pm 11.27 \mathrm{abcd}$ & $77.77 \pm 1.20^{a}$ & $12.80 \pm 0.03$ defgh & $28.54 \pm 1.96^{\mathrm{abc}}$ & $69.07 \pm 1.33^{a}$ & $30.27 \pm 1.17^{\mathrm{ab}}$ \\
\hline & $\mathrm{S}+\mathrm{F} 4$ & $269.0 \pm 16.46^{\mathrm{abcd}}$ & $78.33 \pm 1.51^{a}$ & $13.07 \pm 0.08 \mathrm{fgh}$ & $28.79 \pm 5.63^{a b c}$ & $69.10 \pm 1.71^{\mathrm{a}}$ & $33.13 \pm 5.02 \mathrm{abcd}$ \\
\hline
\end{tabular}


Table 4. Cont.

\begin{tabular}{|c|c|c|c|c|c|c|c|}
\hline \multicolumn{2}{|c|}{ Treatment } & $\begin{array}{l}\text { Falling Number } \\
\text { (s) }\end{array}$ & $\begin{array}{l}\text { Bulk Density } \\
\left(\mathrm{kg} \cdot \mathrm{hl}^{-1}\right)\end{array}$ & $\begin{array}{l}\text { Total Protein } \\
\text { Content }(\%)\end{array}$ & $\begin{array}{l}\text { Wet Gluten Content } \\
(\%)\end{array}$ & $\begin{array}{c}\text { Starch Content } \\
(\%)\end{array}$ & $\begin{array}{l}\text { Wskaźnik Sed. } \\
\text { Zeleny'ego }\end{array}$ \\
\hline & $S+F 1-2$ & $259.7 \pm 17.47^{\mathrm{abcd}}$ & $78.4 \pm 0.72^{\mathrm{a}}$ & $13.73 \pm 0.01^{\mathrm{h}}$ & $30.62 \pm 1.95^{c}$ & $68.73 \pm 0.86^{\mathrm{a}}$ & $34.23 \pm 9.22^{\text {bcde }}$ \\
\hline & $S+F 1-3$ & $265.7 \pm 17.39$ abcd & $78.68 \pm 0.40^{a}$ & $12.57 \pm 0.03^{\text {cdefgh }}$ & $29.78 \pm 1.45^{b c}$ & $68.80 \pm 0.70^{a}$ & $36.67 \pm 2.65$ cdefgh \\
\hline & $S+F 1-4$ & $262.7 \pm 11.72 \mathrm{abcd}$ & $76.50 \pm 0.66^{a}$ & $13.30 \pm 0.05 \mathrm{gh}$ & $29.51 \pm 2.87 \mathrm{bc}$ & $68.73 \pm 0.61^{a}$ & $37.73 \pm 2.35$ defghi \\
\hline \multirow{8}{*}{$\begin{array}{l}\text { Grain, soil and foliar } \\
\text { application }\end{array}$} & $G+S$ & $257.0 \pm 60^{a b c}$ & $78.76 \pm 0.40^{a}$ & $12.23 \pm 0.06^{\text {bcdefgh }}$ & $27.43 \pm 1.58^{a b c}$ & $69.50 \pm 0.53^{a}$ & $32.90 \pm 0.78^{\text {abcd }}$ \\
\hline & $\mathrm{G}+\mathrm{S}+\mathrm{F} 1$ & $279.3 \pm 4.16^{\mathrm{abcd}}$ & $79.06 \pm 0.07^{a}$ & $11.77 \pm 0.03$ abcdefg & $26.12 \pm 0.67^{a b c}$ & $70.07 \pm 0.47^{\mathrm{a}}$ & $34.50 \pm 1.45^{\text {bcde }}$ \\
\hline & $\mathrm{G}+\mathrm{S}+\mathrm{F} 2$ & $251.3 \pm 12.06^{\mathrm{abc}}$ & $77.80 \pm 1.40^{\mathrm{a}}$ & $12.43 \pm 0.03$ bcdefgh & $27.86 \pm 0.93 \mathrm{abc}$ & $68.97 \pm 0.29^{a}$ & $38.30 \pm 1.87$ efghij \\
\hline & $G+S+F 3$ & $250.7 \pm 10.5 \mathrm{abc}$ & $78.58 \pm 0.25^{a}$ & $11.43 \pm 0.03$ abcde & $25.90 \pm 0.72 \mathrm{abc}$ & $70.00 \pm 0.46^{\mathrm{a}}$ & $36.53 \pm 4.17^{\text {cdefgh }}$ \\
\hline & $\mathrm{G}+\mathrm{S}+\mathrm{F} 4$ & $278.7 \pm 13.65^{a b c d}$ & $79.14 \pm 0.4^{\mathrm{a}}$ & $11.17 \pm 0.03^{a b c}$ & $25.45 \pm 2.32^{a b c}$ & $69.93 \pm 0.57^{a}$ & $32.77 \pm 1.44^{\mathrm{abc}}$ \\
\hline & $G+S+F 1-2$ & $286.0 \pm 7.21 \mathrm{bcd}$ & $77.98 \pm 0.14^{\mathrm{a}}$ & $12.23 \pm 0.06^{\text {bcdefgh }}$ & $27.79 \pm 1.56^{\mathrm{abc}}$ & $69.47 \pm 0.45^{a}$ & $37.73 \pm 1.52$ defghi \\
\hline & $G+S+F 1-3$ & $254.7 \pm 20.21^{a b c}$ & $78.02 \pm 0.81^{a}$ & $11.90 \pm 0.02$ abcdefg & $26.69 \pm 1.98^{a b c}$ & $69.93 \pm 1.11^{a}$ & $36 \pm 5.71^{\text {cdef }}$ \\
\hline & $G+S+F 1-4$ & $294.7 \pm 6.03^{d}$ & $78.33 \pm 0.70^{a}$ & $12.53 \pm 0.01^{\text {cdefgh }}$ & $29.06 \pm 0.14^{\mathrm{abc}}$ & $69.40 \pm 0.30^{a}$ & $41.03 \pm 0.71$ ghijk \\
\hline
\end{tabular}

Results show means and standard errors $(n=3) .{ }^{\mathrm{a}}{ }^{\mathrm{b}}, \mathrm{c}-$ means followed by the same letter are not significantly different from one another based on Tukey's test at $p \leq 0.05$. 


\section{Discussion}

The results of this research indicate no negative effects of selenium fertilization on grain yield. This is in line with the results of other research, which involved various fertilization methods and selenium doses (even up to $120 \mathrm{~g} \cdot \mathrm{ha}^{-1}$ ) [27-29]. Some researchers even reported a possible increase in yield as a result of the introduction of this element [30-32], which can be attributed to antioxidant stimulation that contributed to the subsequent protection of plants against abiotic stress, including drought or deficiencies of trace elements [33]. Selenium has been proven to be safe in terms of plant growth without exerting any negative impact on plants [34].

The selenium content in the analysed soil was marginal [35,36], comparable to the soils in places where selenium deficiency symptoms were found in the local population in the past [37]. Thus, the region can be considered deficient in terms of selenium content in soil and plants, as these two parameters are closely correlated. Low selenium content in soil resulted in an equally low selenium content in the spring wheat grain control sample. Each method of fertilization increased the selenium content in the grain. The results confirm that wheat has the potential to absorb increased amounts of selenium without negative effects on the plant. Fertilization increased selenium content in grain to levels even over 0.8 $\mathrm{mg} \cdot \mathrm{kg}^{-1} \mathrm{Se}$. The applied doses of selenium did not result in excessive toxic accumulation of this element in plants, which could pose a threat to human or animal health. The desirable target selenium content in grain that has no toxic effect ranges from 0.1 to 1.00 $\mathrm{mg} \cdot \mathrm{kg}^{-1}$ [38]. Thus, it can be concluded that the biofortification process was successful, and the target values were obtained.

In the experiment, different methods and doses of selenium fertilization were applied. The highest content of this element in grain was observed for a combination of all the methods of fertilization, providing the highest dose of selenium mainly at the stage of stem elongation $(\mathrm{G}+\mathrm{S}+\mathrm{F} 2)$, tillering and stem elongation $(\mathrm{G}+\mathrm{S}+\mathrm{F} 1-2)$, as well as at the stage of tillering, stem elongation and inflorescence emergence ( $\mathrm{G}+\mathrm{S}+\mathrm{F} 1-3)$. However, what is interesting, comparable selenium content was also observed in the case of soil application combined with the foliar application $(\mathrm{S}+\mathrm{F})$ at the same phases. For the remaining fertilization methods, foliar $(\mathrm{F})$ and seed treatment with the foliar application $(\mathrm{G}+\mathrm{F})$, despite lower final selenium content in the grain, a clear increase in selenium content was observed for the foliar application at the stage of stem elongation (F2), tillering and stem elongation (F1-2), as well as tillering, stem elongation and inflorescence emergence (F1-3). Thus, it can be concluded that foliar application of Se at the aforementioned stages increased its content in spring wheat grain. This means that not only the dose of the element but also the developmental stage of the plant in which the element is introduced determines its final content in the grain. On the basis of the obtained results, it was established that the best time for foliar application is the stage of stem elongation (BBCH 30-39), as it is the main stage of the reproductive development of cereal plants, which is characterised by increased demand for nutrients, leading to higher absorption of selenium.

The distribution of selenium in the grain is essential in terms of the suitability of the grain for baking purposes. During processing, the grain is mechanically split into its inner part (i.e., the endosperm and germ) and its outer part (i.e., the seed coat). The main products of milling are bran (from the outer part) and flour (from the inner part). White bread is made only from flour, whereas wholemeal bread is made from both flour and bran. The results of this research indicate that fertilization has an impact on the increase in the selenium content of the inner part of the grain, which is also confirmed by other studies [39]. This may be related to an increased concentration of the supplied selenium in the germ and endosperm, which is the storage of nutrients that the plant uses during growth. This may be key in the production of selenium-enriched bread.

The content of protein and gluten in the spring wheat grain is one of the most important parameters determining the suitability of grain for baking bread [40]. On the basis of the analysis of the quality characteristics, it was found that selenium fertilization only had an impact on total protein content and the falling number. Data found in the literature 
on the subject indicates large fluctuations in protein content depending on the cultivar, cultivation technology or crop year [41,42]. The criteria for the suitability of wheat grain for the production of bread flour in terms of total protein and gluten content are at least $11.5 \%$ d.m. and $25 \%$, respectively $[21,43,44]$. In terms of these two parameters, the most effective method of fertilization was the combination of soil application combined with the foliar application at the tillering and stem elongation stage ( $+F 1-2)$, where additional foliar fertilization was of key importance, allowing to obtain the values of $30.62 \%$ protein and $13.73 \%$ wet gluten. Similar parameters were obtained by Krawczyk et al. [45]. Sztuder and Świerczewska [46], in turn, showed that a marked increase in the amount of wet gluten in grain was the result of foliar fertilization. It was also reported that foliar application, at the stem elongation stage, of a fertilizer containing zinc and manganese, resulted in an increase in total protein [47], while application of a fertilizer containing nitrogen led to an increase in gluten content [48], which is in line with the findings of this research.

In terms of the falling number, the acceptable values for flour with a good technological quality range between 200 and 300 s [49,50]. On the other hand, according to Knapowski et al. [51], the most favourable value of this parameter for grain intended for milling and bread baking should determine the average amylolytic activity and thus range between 220 and $350 \mathrm{~s}$. Lower values result in poorly risen and pale bread. In turn, if the value is higher than the indicated range, it is recommended to mix the flour with other flours [43]. The research results fall within the indicated range. It is believed that the falling number depends largely on the genotype, i.e., cultivar [52], as well as on sowing timing and weather conditions [53]. Experiments with fertilization with nitrogen [52], woody biomass ash [54], as well as manganese and zinc [47] did not affect the value of the falling number, in contrast to selenium fertilization, in the case of which such an impact was observed.

In terms of the bulk density of grain and the Zeleny sedimentation index, the higher the values of these features, the higher the grain quality. The sedimentation index, which to a large extent determines the baking value of wheat flour, should not be lower than 20 $\mathrm{cm}^{3}$ [55] and preferably higher than $30 \mathrm{~cm}^{3}$ [43,44]. A sedimentation index value above $50 \mathrm{~cm}^{3}$ is typical of high-protein wheat containing the so-called "strong gluten" [54]. The obtained results are within the range of $28.83-44.07 \mathrm{~cm}^{3}$ and meet the requirements of grain intended for baking purposes in terms of this parameter. Strong correlations between the sedimentation index, protein and gluten content were also confirmed in other studies [21] According to the guidelines of the Polish Standards, the minimum bulk grain density for wheat is $72 \mathrm{~kg} \cdot \mathrm{hl}^{-1}$ [54]. According to data in the literature on the subject [56], high values of wheat grain density (above $76 \mathrm{~kg} \cdot \mathrm{hl}^{-1}$ ) indicate good grain filling and a high flour extraction rate. The values of this parameter for all the samples were higher than those indicated, and there were no differences in terms of the applied fertilization method. In Poland, the average bulk density of wheat grain is approx. $75.35 \mathrm{~kg} \cdot \mathrm{hl}^{-1}$ [57], while in the conducted experiment, it averaged $77.82 \mathrm{~kg} \cdot \mathrm{hl}{ }^{-1}$. In the study by Dziura et al. [58], grain delivered by farmers to the agricultural research laboratory was characterised by an identical density. Additionally, in an experiment comparing different winter wheat cultivars, similar values were obtained [59].

The starch content in the spring wheat grain in the conducted research did not vary significantly depending on the method of fertilization and the stage of its application. No variability in this regard is also confirmed by other studies [54,60].

On the basis of the obtained results, it can be concluded that the best way to fertilize with selenium in order to obtain a high content of this element while maintaining high-quality spring wheat grain is a combination of intra-seed and soil fertilization with foliar application in the tillering phase and the stem elongation phase $(G+S+F 1-2)$ and the stem elongation phase itself $(G+S+F 2)$, where the full dose of fertilization was $50 \mu \mathrm{mol}+10 \mathrm{~g} \cdot \mathrm{ha}^{-1}$ of Se. Additionally, soil and foliar fertilization in the tillering and stem elongation phase $(\mathrm{S}+\mathrm{F} 1-2)$ and in the stem elongation phase itself $(\mathrm{S}+\mathrm{F} 2)$, where the target Se dose is $\mathrm{g} \cdot \mathrm{ha}^{-1}$ Se allows obtaining a high selenium content and characteristics grains suitable for bread use. 


\section{Conclusions}

The research results indicate that the selenium content in grain depends on both the method of fertilization and the stage at which the element is introduced. The most effective method of fertilization proved to be seed treatment and soil application combined with the foliar application at the tillering and stem elongation stages $(G+S+F 1-2)$, as well as at the stem elongation stage alone $(G+S+F 2)$. Soil application combined with the foliar application at the tillering and stem elongation stages $(S+F 1-2)$ and at the stem elongation stage alone $(S+F 2)$ were found to be equally effective. The highest concentration of selenium was observed in the inner part of the grain. In terms of the quality characteristics, the impact of selenium fertilization was observed only in the case of the falling number and the total protein content; all the parameters allowed for the grain to be classified as suitable for bread-making. Selenium fertilization can be considered as a safe way of increasing the Se content in spring wheat, which may contribute to an increase in the technological quality of the grain and its nutritional value.

Author Contributions: Conceptualization: A.R., W.S. and B.R.; methodology: W.S. and B.R.; software: Not applicable; validation: A.R. and W.S.; formal analysis: A.R., W.S., T.K. and D.G.; investigation: A.R.; resources: A.R., W.S., T.K. and B.R.; data curation: A.R.; writing-original draft preparation: A.R. and J.A.T.; writing-review and editing: W.S. and B.R.; visualization: A.R., W.S. and B.R.; supervision: W.S. and B.R.; project administration: W.S.; funding acquisition: A.R. and W.S. All authors have read and agreed to the published version of the manuscript.

Funding: This research received no external funding.

Data Availability Statement: Data are available by contacting the authors.

Conflicts of Interest: The authors declare no conflict of interest.

\section{References}

1. Velu, G.; Ortiz-Monasterio, I.; Cakmak, I.; Hao, Y.; Singh, R. Biofortification strategies to increase grain zinc and iron concentrations in wheat. J. Cereal Sci. 2014, 59, 365-372. [CrossRef]

2. Shukla, A.K.; Behera, S.K.; Pakhre, A.; Chaudhari, S.K. Micronutrients in soils, plants, animals and humans. Indian J. Fertil. 2018, 14, 30-54.

3. Peng, Q.; Li, J.; Wang, D.; Wei, T.-J.; Chen, C.-E.L.; Liang, D.-L. Effects of ageing on bioavailability of selenium in soils assessed by diffusive gradients in thin-films and sequential extraction. Plant Soil 2019, 436, 159-171. [CrossRef]

4. Sahebari, M.; Rezaieyazdi, Z.; Khodashahi, M. Selenium and Autoimmune Diseases: A Review Article. Curr. Rheumatol. Rev. 2019, 15, 123-134. [CrossRef]

5. Khouzam, R.B.; Lobinski, R.; Pohl, P. Multi-element analysis of bread, cheese, fruit and vegetables by double-focusing sec-tor-field inductively coupled plasma mass spectrometry. Anal. Methods 2011, 3, 2115-2120. [CrossRef]

6. Maurer, J. The pork meat enriched with organic selenium and its effect on selenium concentration and total antioxidant status in healthy volunteers. Biotechnol. Anim. Husb. 2011, 27, 791-798. [CrossRef]

7. World Health Organization. Trace Elements in Human Nutrition and Health; World Health Organization: Geneva, Switzerland, 1996; pp. 105-120.

8. Sonet, J.; Mounicou, S.; Chavatte, L. Nonradioactive isotopic labeling and tracing of selenoproteins in cultured cell lines. In Selenoproteins; Humana Press: New York, NY, USA, 2018; pp. 193-203.

9. Rayman, M.P. Selenium in cancer prevention: A review of the evidence and mechanism of action. Proc. Nutr. Soc. 2005, 64, 527-542. [CrossRef]

10. Combs, G.F. Selenium in global food systems. Br. J. Nutr. 2001, 85, 517-547. [CrossRef]

11. Combs, G.F. Current Evidence and Research Needs to Support a Health Claim for Selenium and Cancer Prevention. J. Nutr. 2005, 135, 343-347. [CrossRef]

12. Lv, Q.; Liang, X.; Nong, K.; Gong, Z.; Qin, T.; Qin, X.; Wang, D.; Zhu, Y. Advances in Research on the Toxicological Effects of Selenium. Bull. Environ. Contam. Toxicol. 2021, 106, 715-726. [CrossRef]

13. Zhou, Y.-J.; Zhang, S.-P.; Liu, C.-W.; Cai, Y.-Q. The protection of selenium on ROS mediated-apoptosis by mitochondria dysfunction in cadmium-induced LLC-PK1 cells. Toxicol. Vitr. 2009, 23, 288-294. [CrossRef] [PubMed]

14. Jat, M.L.; Singh, B.; Stirling, C.M.; Jat, H.S.; Tetarwal, J.P.; Jat, R.K.; Singh, R.; Lopez-Ridaura, S.; Shirsath, P.B. Soil Processes and Wheat Cropping Under Emerging Climate Change Scenarios in South Asia. Adv. Agron. 2018, 148, 111-171. [CrossRef]

15. Hartikainen, H. Biogeochemistry of selenium and its impact on food chain quality and human health. J. Trace Elem. Med. Biol. 2005, 18, 309-318. [CrossRef] [PubMed] 
16. Weber, R. Influence of tillage method and stubble height on the quality features of grain of selected winter wheat cultivars. Sci. Nat. Technol. 2013, 7, 18.

17. Buczek, J.; Tobiasz-Salach, R.; Bobrecka-Jamro, D. Effect of foliar fertilization and reduced doses of herbicide on the yield and quality features of winter wheat grain. Fragm. Agron. 2012, 29, 7-15.

18. Migut, D. Effect of Foliar Fertilization with Dr Green Technology on the Growth, Development, Yield and Quality of Maize Grain. Available online: https:/ / repozytorium.ur.edu.pl/handle/item/6288?show=full (accessed on 1 June 2021).

19. Najewski, A.; Szarzyńska, J. Technological value of wheat varieties. Grain Milling Rev. 2013, 57, 2-6. Available online: https: //yadda.icm.edu.pl/yadda/element/bwmeta1.element.agro-a0b3c9fd-c45a-4491-a01e-e1eec352a55b (accessed on 1 June 2021).

20. Klikocka, H.; Cybulska, M. Influence of nitrogen and sulfur fertilization on the grain yield and quality characteristics of spring wheat. Agron. Sci. 2020, 75, 117-129. [CrossRef]

21. Stepniewska, S. Technological value of grain of selected wheat varieties. Acta Agrophys. 2015, 22, 103-114. Available online: http:/ / yadda.icm.edu.pl/yadda/element/bwmeta1.element.agro-e7add463-2959-4f66-81bb-741dff9aca8b (accessed on 1 June 2021).

22. Kottek, M.; Grieser, J.; Beck, C.; Rudolf, B.; Rubel, F. World Map of the Köppen-Geiger climate classification updated. Meteorol. Z. 2006, 15, 259-263. [CrossRef]

23. Working Group World Reference Base for Soil Resources. The International Union of Soil Sciences. International Soil Classification System for Naming Soils and Creating Legends for Soil Maps. Available online: http:/ /www.fao.org/soils-portal/datahub/soil-classification/world-reference-base/en/ (accessed on 12 December 2020).

24. British Standard ISO 11466. Available online: https:/ / www.iso.org/standard/19418.html (accessed on 20 January 2021).

25. Norm, P. PN-EN ISO 7971-2:2019-03. Cereal Grains-Determination of the Loose Density Called Hectolitre-Part 2: System for Checking Measuring Instruments Against the International Standard Measuring Instrument; Polish Committee for Standardization: Warsaw, Poland, 2019.

26. Norm, P. PN-R-04013: 1988. Chemical and Agricultural Analysis of Plants. Determination of Air-Dry and Dry Mass; Polish Committee for Standardization: Warsaw, Poland, 1988.

27. Ramkissoon, C. Selenium Dynamics in Cereal Biofortification: Optimising Fertiliser Strategies and Assessing Residual Fate. Ph.D. Thesis, University of Adelaide, Adelaide, Australia, 2020. Available online: https://digital.library.adelaide.edu.au/dspace/ handle/2440/126970 (accessed on 10 March 2021).

28. Curtin, D.; Hanson, R.; Van Der Weerden, T.J. Effect of selenium fertiliser formulation and rate of application on selenium concentrations in irrigated and dryland wheat(Triticum aestivum). N. Z. J. Crop. Hortic. Sci. 2008, 36, 1-7. [CrossRef]

29. De Vita, P.; Platani, C.; Fragasso, M.; Ficco, D.B.M.; Colecchia, S.A.; Del Nobile, M.A.; Padalino, L.; Di Gennaro, S.; Petrozza, A. Selenium-enriched durum wheat improves the nutritional profile of pasta without altering its organoleptic properties. Food Chem. 2017, 214, 374-382. [CrossRef] [PubMed]

30. Lara, T.S.; Lessa, J.H.D.L.; de Souza, K.R.D.; Corguinha, A.P.B.; Martins, F.A.D.; Lopes, G.; Guilherme, L.R.G. Selenium biofortification of wheat grain via foliar application and its effect on plant metabolism. J. Food Compos. Anal. 2019, 81, 10-18. [CrossRef]

31. Ekanayake, L.J.; Thavarajah, D.; Vial, E.; Schatz, B.; McGee, R.; Thavarajah, P. Selenium fertilization on lentil (Lens culinaris Medikus) grain yield, seed selenium concentration, and antioxidant activity. Field Crop. Res. 2015, 177, 9-14. [CrossRef]

32. Nawaz, F.; Ashraf, M.Y.; Ahmad, R.; Waraich, E.A.; Shabbir, R.N.; Hussain, R.A. Selenium supply methods and time of application influence spring wheat (Triticum aestivum L.) yield under water deficit conditions. J. Agric. Sci. 2016, 155, 643-656. [CrossRef]

33. Gupta, M.; Gupta, S. An Overview of Selenium Uptake, Metabolism, and Toxicity in Plants. Front. Plant Sci. 2017, 7, 2074. [CrossRef]

34. White, P.J. Selenium accumulation by plants. Ann. Bot. 2015, 117, 217-235. [CrossRef]

35. Tan, J.A. The Atlas of Endemic Diseases and Their Environment; Science Press: Beijing, China, 1989.

36. Kaur, N.; Sharma, S.; Kaur, S.; Nayyar, H. Selenium in agriculture: A nutrient or contaminant for crops? Arch. Agron. Soil Sci. 2014, 60, 1593-1624. [CrossRef]

37. Dinh, Q.T.; Cui, Z.; Huang, J.; Tran, T.A.T.; Wang, D.; Yang, W.; Zhou, F.; Wang, M.; Yu, D.; Liang, D. Selenium distribution in the Chinese environment and its relationship with human health: A review. Environ. Int. 2018, 112, 294-309. [CrossRef] [PubMed]

38. Bañuelos, G.S.; Freeman, J.; Arroyo, I. Accumulation and speciation of selenium in biofortified vegetables grown under high boron and saline field conditions. Food Chem. X 2019, 5, 100073. [CrossRef]

39. Lyons, G.H.; Genc, Y.; Stangoulis, J.; Palmer, L.T.; Graham, R.D. Selenium Distribution in Wheat Grain, and the Effect of Postharvest Processing on Wheat Selenium Content. Biol. Trace Elem. Res. 2005, 103, 155-168. [CrossRef]

40. Rachoń, L.; Kulpa, D. Assessment of the usefulness of durum wheat [Triticum durum Desf.] For the production of bread. Ann. Univ. Mariae Curie-Sklodowska Sect. E Agric. 2004, 59, 995-1000. Available online: https://www.czasopisma.up.lublin.pl/index. $\mathrm{php} / \mathrm{as} /$ article/view/1959 (accessed on 12 March 2021).

41. Rachoń, L.; Krochmal-Marczak, B.; Cebulak, T. Przydatność ziarna jarej pszenicy zwyczajnej, twardej i orkiszowej do produkcji pieczywa w zależności od intensywności technologii produkcji. Agron. Sci. 2020, 75, 25-36. [CrossRef]

42. Radomski, G.; Bać, A.; Mierzejewska, S. A comparative assessment of baking value of wheat flour and German wheat flour. Agric. Eng. 2007, 5, 369-374. 
43. Knapowski, T.; Kozera, W.; Murawska, B.; Wszelaczyńska, E.; Pobereżny, J.; Mozolewski, W.; Keutgen, A.J. Assessment of technological parameters of selected winter wheat cultivars in terms of baking. Inż. Ap. Chem. 2015, 54, 255-256.

44. Knapowski, T.; Szczepanek, M.; Wilczewski, E.; Pobereżny, J. Response of wheat to seed dressing with humus and foliar potassium fertilization. J. Agric. Sci. Tech. 2015, 17, 1559-1569.

45. Krawczyk, P.; Ceglińska, A.; Izdebska, K. Comparing rheological properties of dough and quality of bread made of spelt and common wheat flours. Food Sci. Technol. Qual. 2008, 4, 141-151. Available online: https://agris.fao.org/agris-search/search.do? recordID=PL2009000520 (accessed on 13 March 2021).

46. Sztuder, H.; Świerczewska, M. Influence of foliar fertilizers on the quality features of grains of some varieties of winter and spring wheat. Probl. J. Adv. Agric. Sci. 2002, 2, 669-674. Available online: http://agro.icm.edu.pl/agro/element/bwmeta1.element.agroarticle-06431938-83e9-4b74-8c13-baa1f31d7543 (accessed on 21 June 2021).

47. Augustyniak, B.; Pawłowski, M. Yield and qualitative values of winter wheat grain depending on fertilization with microelements. In Problems of Natural and Technical Sciences; Department of Student Affairs of the University of Life Sciences in Wrocław: Wroclaw, Poland, 2018; pp. 12-17.

48. Spychaj-Fabisiak, E.; Ložek, O.; Knapowski, T.; Ralcewicz, M. The assessment of selected baking parameters of winter wheats under the influence of diverse nitrogen fertilization. Mengen Spurenelem. 2006, 23, 403-408.

49. Cacak-Pietrzak, G.; Ceglinska, A.; Jonczyk, K. The baking value of flour from wheat varieties grown in an ecological production system. Probl. J. Adv. Agric. Sci. 2014, 576, 23-32. Available online: http://yadda.icm.edu.pl/yadda/element/bwmeta1.element. agro-cff644b4-bee9-4a92-8e91-cf7139468888 (accessed on 21 June 2021).

50. Mazurkiewicz, J. Comparison of technological quality of wheat and rye grown in conventional conditions and in an organic farm. Acta Agrophys. 2005, 6, 729-741.

51. Knapowski, T.; Ralcewicz, M.; Spychaj-Fabisiak, E.; Lożek, O. Assessment of winter wheat grain quality under conditions of differentiated nitrogen fertilization. Fragm. Agron. 2010, 27, 73-80.

52. Sułek, A. Selected elements of spring wheat technology grown for milling and baking purposes. Stud. Rep. IUNG-PIB 2014, 41, $117-128$.

53. Sułek, A.; Nieróbca, A.; Cacak-Pietrzak, G. The impact of the autumn sowing date on the yield and quality of spring wheat grain. Pol. J. Agron. 2017, 29, 43-50.

54. Siwek, H.; Sobolewska, M. Wpływ nawożenia popiołem z biomasy i wapnem na cechy jakościowe ziarna, mąki i ciasta z pszenicy ozimej odmiany RGT Kilimanjaro (Triticum aestivum var. Kilimanjaro). Agron. Sci. 2017, 72, 1-9. [CrossRef]

55. Podolska, G.; Sulek, A. The main elements of the production technology that determine the high quality of wheat grain. Putawski's Diary 2002, 130, 597-605.

56. Segit, Z.; Szwed-Urbaś, K. Evaluation of yield structure and technological value of 6 durum wheat (Triticum durum Desf.) lines grain. Ann. UMCS Agric. 2009, 64. [CrossRef]

57. Borkowska, B.; Banach, D. Assessment of selected physicochemical properties of wheat and rye from the northern and southern region of Poland. Ann. Pol. Assoc. Agric. Agribus. Econ. 2018, 20, 18-22. [CrossRef]

58. Dziura, M.; Gorzelany, J.; Migut, D.; Matłok, N.; Belcar, J. Assessment of physical and chemical parameters of wheat grain delivered to the SR San purchase in Głuchów in 2015-2016. Food Process. Eng. 2017, 3, 14-18. Available online: http:/ /yadda.icm. edu.pl/yadda/element/bwmeta1.element.ekon-element-000171503107 (accessed on 15 May 2021).

59. Stępniewska, S.; Abramczyk, D. Relationship between grain quality parameters of selected winter wheat cultivars. Adv. J. Food. Sci. Technol. 2013, 1, 65-78. Available online: https:/ / www.infona.pl/resource/bwmeta1.element.agro-c8d76ab5-38f3-4c8f-864ff26a23c337ff/tab/summary (accessed on 15 May 2021).

60. Miziniak, W.; Matysiak, K.; Kiniec, A. Influence of application of retardants with pinoxaden on selected quality characteristics of winter wheat grain. Prog. Plant Prot. 2018, 58, 203-208. [CrossRef] 